\title{
Storytelling with Actional Function in Haruki Murakami's Hypertexts: Yesterday and Scheherazade
}

\section{Haruki Murakami'nin Hipertextlerinde Performatif İşlevli Hikâye Anlatımı: Dün ve Şehrazad}

\author{
Mustafa Zeki ÇIRAKLI ${ }^{1}$ (D)
}

${ }^{1}$ Assoc. Prof., Karadeniz Technical University, Faculty of Letters, Department of Western Languages and Literature, Trabzon, Turkey

ORCID: M.Z.Ç. 0000-0002-1760-3209

\section{Corresponding author:}

Mustafa Zeki ÇIRAKLI,

Karadeniz Teknik Üniversitesi, Edebiyat Fakültesi, Batı Dilleri ve Edebiyatı, Trabzon, Türkiye

E-mail: mzcirakli@gmail.com mzcirakli@ktu.edu.tr

Submitted: 31.01 .2021

Revision Requested: 16.03.2021

Last Revision Received: 31.03.2021 Accepted: 31.05 .2021

Citation: Cirakli, M. Z. (2021). Storytelling with actional function in Haruki Murakami's hypertexts: Yesterday and Scheherazade. Litera, 31(1), 95-119. https://doi.org/10.26650/LITERA2021-871832

\begin{abstract}
Haruki Murakami uses hypertextual elements as a narrative strategy and frequently represents storyteller characters whose embedded stories have critical -and coreroles in the frame narrative. This article analyses Murakami's fictional narratives Yesterday and Scheherazade, the hypertexts of The Beatles' "Yesterday" and One Thousand and One Nights, from the perspective of hypertextuality, actional storytelling and narrative therapy. Drawing on narrative theories of Genette and Rimmon-Kenan, it examines how the implied author explores actional function in two hypertextual narratives, making references to the previous texts (hypotexts) and representing the storytellers in search of narrative relief in a far-fetched world of everyday life with seemingly trivial problems. The discussion focuses on two storytellers: the characternarrator as the second self of the implied author and a female storyteller living on the experiential tales of life. It argues that both storytellers exhibit a desire to narrate to transform their experiences into verbal expression and to repair their episodic memory through the act of storytelling. The study shows that the characters' stories and the references and allusions to other texts are essential parts accounting for the character's motivation beneath the storytelling and presents the central theme of the narratives. These stories additionally explore the power of storytelling as to whether storytelling can transform the everyday experience into something special worth telling.
\end{abstract}

Keywords: Genette, Murakami, hypertext, storytelling, actional function

öz

Haruki Murakami, hipermetin ögelerini bir anlatı stratejisi olarak kullanır ve hikâyelerinde başka metinlere atıf yaparken sıklıkla anlatıcı karakterlere yer verir. Bu karakterlerin ikincil anlatıları ve başka metinlere yaptığı göndermeler çerçeve anlatı içinde önemli, hatta temel roller üstlenir. Bu makale, The Beatles'ın "Yesterday" şarkısı ile Binbir Gece Masalları'nın hipermetinleri olan Murakami'nin Dün (Yesterday) ve Şehrazad (Scheherazade) adlı kurgu anlatılarını hipermetinsellik, aksiyonel anlatım ve anlatı terapisi perspektifinden analiz etmektedir. Genette ve Rimmon-Kenan'ın anlatı teorilerinden yararlanan çalışma, başka metinlere (hypotekst) göndermeler yapan iki metinde anlatıcı karakterlerin anlatımlarının aksiyonel işlevini irdelemektedir. Çalışma, 
örtük yazarın iki hipermetin anlatısında, günlük yaşamın uzağında, soyutlanmış yaşamlar süren anlatısal sağaltım arayışındaki hikâye anlatıcılarını nasıl resmettiğini ve bu anlatıcıların sıradan görünen derin sorunları hikâye anlatarak nasıl aştıklarını incelemektedir. Tartışma iki hikâye anlatıcısına odaklanır: örtük yazarın ikinci benliği olarak karşımıza çıkan karakter-anlatıcı ve deneyimsel yaşam öyküleri anlatarak var olan bir kadın hikâye anlatıcısı. Çalışma, her iki hikâye anlatıcısının da deneyimlerini sözlü anlatıma dönüştürmeye; belleği onarmak için hikâye anlatmaya ve hikâye anlatma performansına arzu duyduğunu savlamaktadır. Buna göre, hikâyeler ve diğer metinlere yapılan atıf ve anıştırmalar, karakterlerin hikâye anlatımının alıındaki motivasyonu açıklayan önemli parçalardır ve anlatıların asıl temasına hizmet etmektedir. Sonuç olarak, bu hikâyeler aynı zamanda hikâye anlatımının günlük deneyimi anlatılmaya değer özel bir şeye dönüştürüp dönüştüremeyeceği konusunda hikâye anlatımının imkânlarını araştırmaktadır.

Anahtar Kelimeler: Genette, Murakami, hipermetin, hikâye anlatma, aksiyonel işlev 


\section{Introduction}

Virtually all conventional criticism envisages a launching pad for critical reading and commences from the assumption that art is a mimetic activity that mirrors life and reality in some form of representation. Modern criticism considers an existing textual realm, where texts endlessly resonate, setting up new connections and communications with other texts. Murakami's contemporary classic Men without Women (Murakami, 2014) epitomises this. Particularly, Yesterday and Scheherazade in the collection are characterised by a dialogue with other texts. In these stories, Murakami problematises the act of storytelling and the recovery of the past, which brings about authorial sardonic humour and acute self-consciousness.

Murakami's oeuvre recurrently draws on the performative function of storytelling. Yeung states that "from a wider perspective, Murakami foregrounds storytelling in his art because he believes that story has a function that it alone can perform" (Yeung, 2016, p. 9). According to Murakami, a storyteller can "transform the things and events around us into the metaphor of the story form" (Yeung, 2016, p. 9).

Storytelling breaks up the boundaries of the text and opens up new perspectives before the readers since storytellers' recurrent references to other texts recontextualise the texts and set up new connections. This article analyses Murakami's two stories from the perspective of these connections that appear in the form of hypertexts, emphasising how the author employs intertextuality to reinforce his themes and complicate his story worlds. Using Genette's (1992, 1997) and Rimmon-Kenan's (2002) terminologies, the study analyses the hypertextual structure concerning the alluded texts. The study argues that textual references in Yesterday and Scheherazade get beyond the limits of allusions and emerge as hypertexts that indicate a significant actional function. The study discusses the storytellers concerning their actional function that appears through the unfolding of the events. The discussion focuses on the characters' use of hypertexts from two perspectives: (a) allusive references to the previous texts; (b) texts as a reproduction of a previous text; and (c) texts as a performance. These hypertexts enhance the stories with further dimensions of Murakami's isolated characters and help re-write the previous texts (hypotexts) either in the form of manipulation or reproduction. 


\section{Theoretical background: Hypertexts with actional function}

Murakami, opening up new perspectives for the reception of the texts, employs literary references to expand the story worlds. His non-linear narratives with intertextual elements remind us of the non-linear narratives in James Joyce's Ulysses (1922), Jorge Luis Borges' The Garden of Forking Paths (1941), Vladimir Nabokov's Pale Fire (1962), Julio Cortázar's Hopscotch [Rayuela] (1963), and Italo Calvino's The Castle of Crossed Destinies (1973). These texts are hypertexts of the previous texts and indicate intertextual references that emerge at a state of performance (actional representation). In the story Yesterday, Kitaru's song references a precursor text, the Beatles" "Yesterday". The character performs the popular song in his own version, and the narrator narrates his story retrospectively in his own way. In the story Scheherazade, the storyteller does not imitate the theme, but the motif as Irwin suggests: "Hikâya in modern Arabic means 'story', but originally the word meant mimicry, and the hakiya was a mimic" (Irwin, 2004, p. 106). Thus, the female storyteller's performance indicates a double mimicry of the storytelling princess in One Thousand and One Nights (18th Century) ${ }^{1}$ and the tales extracted from fact and fantasy.

Murakami's Yesterday and Scheherezade included in his collection Men without Women (2014) represent the characters with a'performance' of storytelling, indicating an actional function. It can be said that the reader can find a 'Scheherazade' (narrator) in Yesterday (story-text) and a'yesterday' (Scheherezade's past) in Scheherezade (storytext). Such intertextual correspondence suggests that the storytellers with episodic memories transform their pain into the act of storytelling.

As regards Yesterday, it reveals the episodic memory of the narrator and his idiosyncratic friend Kitaru. The title refers to the Beatles' classical song Yesterday (1965). Murakami exploits his own experience in Japan: He says in an interview that "I want to write about Japan, about our life here" (Poole, 2011, October). He also says that it was "too boring" and "too sticky" to live in Japan. Yesterday is a good example where the author"writes about us [Japanese characters]" (Poole, 2011, October). The story represents two performances: The narrator's "narration" and Kitaru's new version of the Beatles'

1 It is also known as the Arabian Nights. Galland published One Thousand and One Nights or The 1001 Nights between 1704-1717 in Europe. The tales have influenced many writers all over the world since then. Routledge reprinted the collection under the title of The Book of the Thousand and One Nights in 1964. Jullien argues that this western experience "traveled back to the Orient, inspiring novelists" (p. 6) such as Murakami. 
song. The sensitive narrator, who eventually reveals himself to be a writer (storyteller), recollects the past and repairs his'yesterday'through the act of storytelling. His memory of the central character Kitaru is still alive. He remembers the story of Kitaru, and he smiles at how he responded to social impositions: He weirdly insisted on learning Kansai dialect, re-writes Paul McCartney's song and performs it in the tub. Kitaru does not want to be a social or cultural alien, and he seems to try to survive in Japanese culture, yet in his own ways. He wants to be a different person than 'himself'. He eventually takes shelter in his fantasy world.

As for Scheherezade, set in a flats isolated world, it represents two characters, a homebound man (Habara) and a caretaker woman (unknown but referred to as Scheherezade). The man's only contact with the world is Scheherazade, who regularly visits the man to clean the house, cook for him, and bring him groceries, books, and DVDs. What is curious in the story is that they hardly have a conversation but have sex, and the woman tells him stories in bed. Their affair turns into a ritual with the stories told by the woman. The female storyteller constructs a new self through storytelling. The name of the woman is not given in the story, but the man calls her'Scheherezade' as he compares her to the original character in One Thousand and One Nights. Through a mise an abyme effect, the story makes certain references to the female storyteller in the classical tales. The traditional storytellers would appear on the marketplace of the towns in the middle east, but the female storyteller Scheherazade was a subversive figure of privacy. That tradition calls for "meditation on the mysterious origins of" (Irwin, 2004, p. 103) the novelists. Scheherazade, as an insubordinate female storyteller, marks a twofold dialogue between the precursor storyteller and the female sensitivity. Hence, their sexual and textual (storytelling) relationship becomes an unusual way of communication.

Gérard Genette (1997 [1982]) develops a framework for the theoretical and practical study of intertextual relationships in the opening pages of his Palimpsests. He suggests that there are actual or possible links between the earlier texts (hypotexts) and the later ones (hypertexts). Authors produce hypertexts, and writing refers to an act of 'reading', 're-writing' or 'reproducing' the previous texts. Genette, in search of the interconnections between the European narratives, shows that texts written in Latin and ancient Greek are reproduced in Italian, Spanish, German, French and English. He further suggests that interconnectedness is an open-ended phenomenon. This study, for example, examines the explicit interconnectedness between the texts originally produced in Japanese, Arabic and English. 
Murakami's texts should be analysed concerning their relationship with the earlier texts since he frequently uses manifest or hidden references in his fiction. The titles Yesterday and Scheherazade obviously hint at intertextual relationships with other texts. These titles refer to intertextual cases as Genette argues: "all that sets the text in a relationship, whether obvious or concealed, with other texts (Genette, 1997, pp. 1-2). Genette is interested, to put in his own terms, only in the "textual transcendence" of the texts, which "brings [them] into relation (manifest or hidden) with other texts" (Genette, 1992, p. 82). Genette discusses the issue under the heading of transtextuality, a subgroup of intertextuality. Hypertextuality, as a subcategory, refers to"any relationship uniting a text B (which I shall call the hypertext) to an earlier text A (I shall, of course, call it the hypotext), upon which it is grafted in a manner that is not that of commentary" (Genette, 1997, p. 5). Murakami's stories Yesterday and Scheherazade are hypertexts, and, interestingly enough, have some "metatextual" implications, too. They provide the reader with commentary, explicit comparison and obvious contrast with the hypotext(s), around which the stories are oriented. In the case of hypertextuality, "a text B may not "speak" at all about text A and yet still not be able to exist, as such, without A" (Genette, 1997, p. 5). Thus, we can argue that "hypertexts derive from hypotexts through a process what Genette calls transformation (text B evokes text $A$ ). In Murakami's case of hypertextuality, the texts $B_{1}$ and $B_{2}$ ("Yesterday" and "Scheherazade") do not "speak" at all about text $A_{1}$ and $A_{2}$ respectively, and yet still not be able to exist, as such, without $A_{1}$ and $A_{2}$. Thus hypertexts $B_{1}$ and $B_{2^{\prime}}$ figuratively put, textual "lampreys" in Scheherazade's terms $\left(B_{2}\right)$, derive from previous texts (hypotexts) through transformation, as suggested by Genette, thereby evoking, yet assimilating and manipulating, texts $A_{1}$ and $A_{2}$ in different contexts. The performative imitations of the acts of singing and telling correspond to the simple and direct transformation of the hypotexts: The Beatles' classic song's lyrics "Yesterday" (1965) and the classical collection of the tales One Thousand and One Nights (18th Cent.).

As regards the modes of hypertextual transformation, Genette makes a distinction between parody and pastiche (1997, pp. 12-18) and highlights the transformation with and without a "satirical intent" (p. 25). Further, he develops another taxonomy comprising parody, travesty, and caricature with the satirical/non-satirical aspects. He additionally differentiates between playful, satirical, and serious moods (p. 26). Combined with the contrast between transformation and imitation, Genette's approach yields a grid of six possible hypertextual modalities (p. 27) and provides numerous examples from world literature(s). These hypertextual possibilities include"playful transformation (=parody), 
satirical transformation (=travesty), serious transformation (=transposition), playful imitation (=pastiche), satirical imitation (=caricature), and serious imitation (=forgery)" (p. 28).

The intradiegetic levels of storytelling in the texts under consideration indicate an acute and sheer'seriousness'. It is observed that the mode of transformation and transfer adopted by the characters attempt to establish new types of modality, but not a generic subversion. Allen discusses Genette's concerns as to the "intended and self-conscious relations between texts" and argues that "hypertextuality marks a field of literary works, the generic essence of which lies in their relation to previous works" (Allen, 2000, p. 108). As for the hypertexts under consideration in this paper, the mode of hypertextual transformation used in the texts is playful and serious on different levels of storytelling. There is an apparent playfulness on the implied author's level, but on the intradiegetic levels, where the storyteller characters appear, the mode of transformation indicates seriousness. There is an evident playfulness on the implied author's level, but on the intradiegetic levels of storytelling, the mode of transformation is adopted by the character's seriousness. The characters imitate the previous texts for serious reasons and in a performative way. In both cases, the transformation makes sense and never arouses a sense of laughter on the ground that the comparison is ludicrous or improper. Nor do these references to the hypotexts deride, parody or poke fun at the previous texts. Rather, the stories imply considerable power to the precursors imbued with a certain sense of respect and meaning. However, on the intradiegetic levels, there are moments when the reader may think that the central character in Yesterday is a caricature of the earlier text or the female storyteller in Scheherazade is a mimicry of the earlier storyteller. The tone of narration carefully erases these implications, and the references explicitly link the characters. It is obvious in the explicative and meaningful transformation through the serious mood adopted by the stories. The manifestation of the non-satirical mode of transformation indicates the playfulness of the author, which helps understand the difference between mere imitation and what Genette calls transformation. ${ }^{2}$ These pastiches, therefore, are used in a sophisticated technique displaying the art of the author.

We should stress the 'actional function' of these stories regarding their function as hypertexts. Their intertextual relationships with the previous texts are overt and explicit

2 The distinction between hyper- and hypo- is of operational significance as to the transformation and imitation. 
in the present case. They are non-linear narratives that assume previous texts as their frame or secondary narratives, holding a continuous communication. Yesterday refers to the Beatles' song, and Scheherezade refers to One Thousand and One Nights. These stories produce interactive narratives in different contexts. Hence, categories of narrative functions may apply to these stories. Rimmon-Kenan's "explicatory, thematic and actional functions" (Rimmon-Kenan, 2002, pp. 91-92) set up intratextual links within the hypertexts and extratextual links with the hypotexts, particularly in terms of actional function'. Rimmon-Kenan maintains that rather than the content of narration, the narrating action itself is significant (p. 92). The actional units are part of characterisation, where storytelling turns out to be actional in that it helps to construct the character. In the stories to be analysed, the very act of storytelling is as important as 'what is being told'. In other words, the narrators narrate, or the storytellers tell to perform an act (Yesterday) or to construct a self (Scheherezade). These narratives can be considered 'metadiegetic' narratives, and this technique of "stratification of levels" (p. 91) can be extended with infinite combinations inside and outside the text. Each metadiegetic narration (second degree or third-degree narratives) contributes to or manipulates the main (first degree) narrative or vice versa. Genette (1982) states that these embedded parts "maintain or advance the action of the first narrative by the sheer fact of being narrated" (p. 92).

As a final crucial critical remark before moving on to the analysis, we should note that Murakami's texts hardly produce a 'parody effect' because they are not a mere re-writing of the previous texts. Nor do they ridicule the previous texts. Instead, they reproduce different versions of the previous 'performances'. What is significant here is that these stories cannot be read or interpreted regardless of the performances represented by the hypotexts. The characters in Yesterday and Scheherazade have something in common with the originators or characters of the previous texts.

\section{Hypertextuality beyond allusive literary references: Yesterday}

In Men without Women, Murakami appears as a keen observer, apart from his utmost sensitivity towards the vulnerable sides of the characters, but, as an (implied) author, he relinquishes the managerial role to orient the execution of storytelling, which, in the present context proves to be an'act' having genuine performativity. It is represented in the narrator's case, which depicts the reader as telling a story of'yesterday'. Murakami's Yesterday is marked with numerous literary allusions. He uses almost the same strategy 
of playing with the title as with his masterpieces 1 Q84 and Norwegian Wood, which refer to concurrent fictional and real periods of 1984 and a popular song. Similarly, his Men without Women (2014) alludes to the title of Hemingway's short story collection and includes stories that are partly reworkings of certain previous texts. Heather $\mathrm{H}$. Yeung (2014) argues that "pop music sits in the pantheon of high and low cultural references which provide Murakami's work with both popular appeal and, at times, complex intertexts" (p. 1-2). Murakami prompts a non-linear narrative interaction in Yesterday, which represents two concurrent fictional stories (that of the narrator and Kitaru's), and two songs: the Beatles' "Yesterday" (song) and Murakami's "Yesterday" (text-story). In other words, each narrative agent deals with their own "yesterday". The story turns out to be a hypertext and, therefore, cannot be interpreted regardless of Paul McCartney's song. The author, the narrator and the characters (Kitaru and Kitaru's girlfriend) are all devoted -and somewhat enthusiastic- storytellers. The actional function of their narratives is obvious in their storytelling: The characters recurrently tell their stories to the narrator, and the narrator tells a story to the readers.

Table 1: Transformative Taxonomy of Yesterday

\begin{tabular}{|l|l|l|}
\hline $\begin{array}{l}\text { Hypotext: Yesterday (The Beatles) } \\
\text { Hypertext: Yesterday (Murakami) }\end{array}$ & serious transformation & (=transposition) \\
\hline $\begin{array}{l}\text { Author } \\
\text { The implied author }\end{array}$ & playful imitation & (=pastiche) \\
\hline $\begin{array}{l}\text { Character } \\
\text { The narrator's perspective 1: }\end{array}$ & satirical imitation & (=caricature) \\
\hline $\begin{array}{l}\text { Narrator (Homodiegetic) } \\
\text { The narrator's emphatic perspective 2: }\end{array}$ & serious transformation & (=transposition) \\
\hline $\begin{array}{l}\text { Character } \\
\text { Kitaru's perspective: }\end{array}$ & serious transformation & (=transposition) \\
\hline
\end{tabular}

The hypertexts are not only meaningful but also functional in Yesterday. Murakami produces his version of "Yesterday", which includes hypertexts having a function of 'restoration' for the author, the narrator and the character. Hence, it can be argued that the narrator's keen and palpable storytelling can be read as a sign of 'actionality' concerning the Beatles' hypotext (the song). Hence, Yesterday (the story) represents how the implied author or the narrator reviews himself from within and attempts to alleviate the past (yesterday) telling this story. In this story, the act of storytelling (written or oral) signs a performance. Hence, Yesterday refers to four different, yet related, performances at a time:The Beatles'song performance, the author's written performance, the narrator's narration, the character's re-writing of the song and his singing it. The story represents the sensitivity of the author, the narrator and the character and depicts 
them roaming around the episodic moments of the past. The implied author explores how individuals cope with the episodic memories, the narrator seeks to repair the past by telling the story of the central character, and the character re-writes a melancholic song to create a fantasy world of his own.

Firstly, the very text implies actionality in that Murakami, as a playful author in Genette's sense, presents the reader with a performance, the writing of the text. His story communicates with an earlier song, adding to and borrowing from it. Yet, Yesterday (story) as hypertext that is portrayed as having a dialogue with Paul McCartney's hypotext "Yesterday" (song) calls for further consideration of its actional function as well as transtextual relationships with the other texts. Rather than searching for the 'real', Murakami, on a theoretical and performative level, attempts to repair and restore reality through storytelling. His retelling of a previous story (Yesterday) indicates an actional function as the Beatles' song is not only're-written' but also're-performed' by the text. It has a function in the lives of the author, the narrator and the central character (Kitaru).

Murakami's story with the title Yesterday (2014) incorporates artistic mimicry and textual referencing. The author, like Paul McCartney, tells us about the human condition, mourning for the past through the sensitive first-person narrators. However, Murakami's narrator implies that he is a storyteller, seeking to recuperate from a sad memory of the past, a restoration of "yesterday" in the form of art and storytelling. Narration turns out to be a performance for him, and he gives the impression that he would not go on if he did not tell Kitaru's story. Even though he did not keep a journal or diary about Kitaru (Murakami, 2014, p. 75), he still remembers Kitaru (p. 75) and his story, which shows that the narrator's episodic memory is still active. As a discursive response to a previous song, Murakami explores what draws the narrator to Kitaru and what attracts him to his "yesterday".

The author represents how Kitaru copes with loneliness and how he deals with the past and the present. The title of the story, "Yesterday", calls into question the narrator and the character's experience of time. Hence, time is the central theme in this story, particularly from the narrator's point of view and the implied author. "Yesterday" is not only a Beatles song but also appears as a theme, as a motif, a myth, and a hypertextual element in the story. The narrator, adopting an extradiegetic stance, tells the story'from without' in a manner of retrospection and recollects the past. The remembrance of the 
past, curing and hurting, is transformed into the act of storytelling, which, in a way, leads to the re-experience of time. The central character's class conscious discourse at the beginning of the story (when they met at Waseda college ${ }^{3}$ ) hints at a biographical detail from the life of the historical author. The narrator increasingly becomes interested in Kitaru's life, and his involvement in the life of the idiosyncratic character is conspicuous in the story: "But, oddly enough, I remember Kitaru so well (empathy, telling the story as if it were his). We were friends for just a few months, yet every time I hear "Yesterday" scenes and conversations with him well up in my mind" (p. 43). Their friendship grew beyond official college acquaintance, and they frequently hung out together since they became closeT friends in a short time. It lasts "for just a few months" but is still alive and vivid in the memory of the narrator and the implied author. "It feels as though these things happened just yesterday" (p. 75), says the narrator. They talk about family -and what it is to be a Japanese man - language, baseball, music, lessons, exams, girls, sex ... and about everything. The effect of the past makes our present heard and felt through the currency of life and overwhelms "the 'sticky' culture of Japan" (Murakami, 2010, October). Murakami suggests that he is exclusively concerned with the stories of the characters, who helplessly desire to construct a past instead of a future. Kitaru, for example, cannot'appropriately' abide by the present, and his very act of'reproduction' of a previous text is an attempt of incongruous'appropriation' since his intended copying or alteration of the preexisting song proves ridiculous. Yet, it is a sign of the fact that Kitaru cannot stick to present reality and cannot envisage a future since he does not have a past (yesterday). Murakami's narrator's interest in Kitaru is also noteworthy here. He carefully observes the character and finds this unusual character so intrinsic:"When he was free, he read a lot, but nothing related to the exam - a biography of Jimi Hendrix, books of shogi problems, Where did the Universe come from? And the like" (p. 42). Hence, his reference to McCartney's song is keenly and poignantly acute in that he does not have a past to'yearn'. Past for Kitaru is not a loss but a lack in Lacanian sense. His story is a reversed version of the story told by the Beatles. The hypertext produced by Kitaru is, therefore, an attempt to revise and repair the lack of the past on a textual and performative level indicating the actional function of the hypertext.

The text/fiction, the narration/memory and the song/reproduction provide the author, the narrator and the character with spatial realms, respectively. The alluring and alleviating power of spatiality manifests itself in their discursive performances. The narrator eventually becomes an author, writing this story, and Kitaru leaves Japan to 
pursue his dream. The narrator-author resides in a fictional world and the character shelters in a fantasy world alienated from the temporality of life. Both seek to find restoration in their semiotic realm apart from the symbolic or the temporal arrangements of life. Kitaru's desire is not only to resist social expectations, but also he also desires to exist through his semiotic language (Yesterday as a hypertext) or spatial experience (the moments when he sings in the tub or the postcard). Even sex is something special and spatial for him, and both characters are so sensitive -and vulnerable - to temporality. It is observed in Kitaru's "sexual insecurity" (Mukherjee \& Swami, 2019, p. 69) and his performative "shower in the tub" (Murakami, 2014, pp. 47-48). It is a sign of his "desire to escape or desire to perform the song the way he likes. From the narrator's perspective "the familiar melancholy melody" in the Beatles' song is removed from Kitaru's version, in which the song is "paired with the breezy Kansai dialect" (p. 42).

The narrator, as a sensitive storyteller, makes numerous references to the previous texts. The narrator alludes to Coleridge's famous moment of "a spring of love gushed from my heart" (Coleridge, 1982 [1878], p. 40) when the full moon appears as an important symbol in the text. It is a gesture for the utmost empathy for the other creatures/characters from The Rime of the Ancient Mariner. The scene implies that the narrator almost repeats the same idea in a different context. His affection and sympathy for his characters provide a therapeutic effect for him, a recurrent motif in Murakami's fiction. The narrator becomes a focalizer in the scene. He focalises the moon as was described earlier by Kitaru's ex-girlfriend. The oversensitive narrator-focalizer's perspective sheds on the image of the full moon (a moon made of ice), which appears as a metaphor for the heart: "At the time I felt as if every night I, too, were gazing out a porthole at a moon made of ice. A transparent, eight-inch-thick, frozen moon. But I watched that moon alone, unable to share its cold beauty with anyone" (Murakami, 2014, p. 76).

Thirdly, the eccentric central character Kitaru is portrayed as trying to adapt himself to social life: "As far as I know, the only person ever to put Japanese lyrics to the Beatles song "Yesterday" (and to do so in the distinctive Kansai dialect, no less) was a guy named Kitaru" (Murakami, 2014, p. 42). Kitaru's reproduction of the Beatles' song amounts to a parody of Paul's lyrics. In the Beatles' original version, the past is still so warm and haunting and so close as to be two days ago for McCartney's speaker, who has a strong desire to turn back to the past. Kitaru's imaginary past, however, takes a glimpse at a fantasy where there is little space for others. 


\title{
Suddenly
}

I'm not half the man I used to be

There's a shadow hangin' over me

Oh, yesterday came suddenly

Why she had to go, I don't know, she wouldn't say

I said something wrong, now I long for yesterday. (McCartney, 1965, track 13)

Kitaru re-writes the song and produces a cover version of the song. Kitaru's hypertextual lyrics with an unfamiliar performance sound almost meaningless and have little to do with the original words. He does change not only the lyrics but also their mode and effect. He almost invents his own version:

\author{
Yesterday \\ Is two days before tomorrow, \\ The day after two days ago. (Murakami, 2014, p. 76)
}

Kitaru's song arouses a particular effect of parody, but this imitation/reproduction is not intended to make fun of the Beatles' song. The author represents the naivety of the character, and this serious pastiche, in Genette's terms, is aimed at characterisation. The laughter and derision culminate into sympathy, represented by the narrator. Kitaru does not care about how he changes the song and performs the song as if it were the Beatles' Yesterday. In the scene when they talk about the writer of the song, whether it was Paul or John, he does not take it seriously and reproduces and performs it the way he wishes. He does not care about the real author of the song, either Paul or John. It seems that Kitaru creates his fantasy world to cling to life: "It feels as though these things happened just yesterday" sounds like a mimicry of the lyrics "Dreams are the kind of things you can borrow and lend out" by Paul McCartney.

Murakami's characters are frequently portrayed as "loners, who are isolated from society" (Strecher \& Thomas, 2016, p. 5). The text implies that the narrator is an author -probably that of the present story, and has a motive to explore such an odd and lonely character. The narrator increasingly sympathises with Kitaru and shows a growing affection for him. He realises that Kitaru is not a lazy, stupid or absent-minded person. He is just different and has a different world of fancy. Kitaru resists studying hard for entrance to an elite college and always seems busy with somewhat trivial things from the outer perspective. He refuses to comply with the expectations of society. At the 
outset, the narrator is puzzled by his pointless rejection of regularity and questions his sporadic interest in hobbies and other things. However, he understands later that Kitaru rejects the image of himself in the mirror of his mother and his girlfriend. The narrator, at this point, supports him and develops a reliable bond with him. Kitaru shows his trust in him by asking him to go out for dinner with his girlfriend. The centrality of the Kansai dialect as a motif is noteworthy in this context since it plays a significant role in the story. Kitaru invests considerable time on it and makes great efforts to acquire the dialect: "He hit the high notes especially well. "Tho' she was here / Til yesterday ..." (Murakami, 2015, p. 48). Thus, Kitaru's desire to be a different person in an utterly different way and sort of class consciousness in giving details about his family indicates that he wants to be part of society, but in a way, he dissatisfies the expectations and disappoints his mother and girlfriend. He resists a success-driven society, and he questions the expectations of the culture. It reminds us of Strecher's (2002) argument that the character's resistance signifies a 'wilful act.' He maintains that "while most Murakami characters are passive, they are not devoid of identity; rather, their passivity, [...], stems from their inability to decide how to act without participating in the consumerism that surrounds them, thus maintaining their sense of individuality" (Strecher, 2002, pp. 94-95). He, therefore, insists on inventing new lines and changes the lyrics of "Yesterday", the Beatles' famous song.

'Yesterday' (memory) emerges as a prevailing force behind the existence through the lines. The present is missing in the songs, and the past and the future are caught up by the fantasy world of the character. The storyteller tells the reader about Kitaru, his old -and odd - friend. Kitaru was obsessed with the Kansai dialect (one of the dialects in Japan). The idiosyncratic and intrinsic character Kitaru put the Beatles famous lyrics to Kansai dialect sounding so weird. Somewhat ludicrous Kitaru is not a storyteller looking reflectively back at his youthful past, nor does the same man talking to his former girl about what could have been. Kitaru, instead, turns out to be a parody of Paul's speaker, singing beyond the limits of the past and present, "Is two days before tomorrow, / The day after two days ago". The suggestive re-writing of the previous text is accompanied by a lot of familiar themes, and images from the books cropped up in the story. The allusions to the Beatles'"Yesterday" (Murakami, 2014, p. 41); to Jimi Hendrix (p. 42); to H.G. Welles' Where did the Universe come from? (p. 42), to a well-known Japanese novel Sanshiro, a typical "country-boy-bumbles-his-way-around-the-big-city story" ( $p$. 43), to Salinger's "Franny and Zooey" and to a Woody Allen movie set in Paris refer to hypertextual allusions. Woody Allen's "Midnight in Paris" (Aronson et al., 2011), a fantasy 
romantic comedy, explores modernist art, history and postmodernist elements of parody. The film represents a storyteller (a screenwriter) and investigates the limits of mimetic art and intertextuality. The movie also problematises the theme of 'yesterday', blurring the boundaries between fiction and reality. That Kitaru uses them to construct his fantasy world shows that Kitaru's life imitates art. Oscar Wilde's idea is represented in Kitaru's spatial, semiotic and somewhat fantastic world. It seems that in Kitaru's context, these hypertexts are in service of the construction of his fantasy world.

Kitaru's reference to McCartney's "Yesterday" (song and lyrics) has further suggestions and implications on different levels. The symbolic value of the title clues at the character's desire for self-construction as well as his social struggle to abide by society. "Yesterday" overwhelms is a mere sign of mourning for the past (loss) but also a sign of melancholic aspiration for the unachievable past. Textual correspondence on a synchronic level is complicated by a diachronic dimension in the history of the character. Beatles' song refers to an intertextual relationship with the original lyrics (hypotext) but also an intratextual relationship with Kitaru's version within the story world, signifying his craving for the semiotic realm maternal space -Kristevian poetic verbal production (1989: 158-160). Kitaru's alienation (or resistance) to the symbolic ends up in his manipulation of the lyrics along with the history of the song. That is a form of parody making Kitaru's enunciation roaming on the fringes of wry comedy. The implied author's use of the "shover tube" (Murakami, 2014, p. 47), where Kitaru performs the song, turns out to be a metaphor for his fantasy world where his version of the song is acclaimed by the very performer, who is also the sole audience. The doubles in the story are the narrator (Tanimura, the one pursuing a career) and the character (Kitaru, pursuing his spontaneous experience); the real writer of the lyrics (Paul) and the so-called writer (John); the voice of social consciousness (his girlfriend Erica) and another voice of social consciousness (his mother).

Kitaru's idiosyncrasy is also obvious in his reference to Jimi Hendrix, which is used by the implied author as an explicative gesture and analogy for the character. Jimi's unusual interpretation of performative music provides a point of comparison and reasonable analogy with Hendrix, a master of unusual pitches and weird tones with high volume in the electro-guitar. Jimi Hendrix is associated with amplifiers with highphonic sound. This can be read as an implicit reference to the dejected character, whose voice may sound 'annoying' and 'ludicrous' but imply invisible grief. The narrator says: “To my ear Kitaru had an almost pitch-perfect Kansai Accent" (Murakami, 2014, p. 42). 
The speakers of "standard" Japanese characterise the Kanzai dialect as sounding "more melodic" and "harsher". Hence, the playful author sets up a striking paradox since Hendrix was famous for his'negative feedback amplifier'. The situational irony produced by the playful author is clear here. Kitaru tells the narrator that he studied hard verbs, nouns, accent-the whole nine yards and improved his accent. The narrator-character is impressed by Kitaru's engaging account: He asks: "So there were people who studied the Kansai dialect as if it were a foreign language? That was news to me. It made me realise all over again how huge Tokyo was and how many things there were that I didn't know. It reminded me of the novel Sanshiro, a typical country-boy-bumbles-his-wayaround-the-big-city story" (p. 58).

Kitaru seems concerned with the external world rather than himself but entrapped within his anxieties and fantasies. His vast and unorganised interest in books, movies, and sport shows that he tries to cling to society. The more he tries to adapt himself, the further he becomes alienated. His reference to the Beatles and the author's reworking of a different 'yesterday story', therefore, turns out to be a sign/code of Kitaru's hypertextual inclinations in his pursuit of meaning. The narrator's initial bafflement soon turns to curiosity:"I was kind of surprised that I could adapt so quickly. Maybe I'm a chameleon, and I didn't even realise it. Or maybe my sense of language is more advanced than most people's" (Murakami, 2014, p. 45) Kitaru tells the narrator how he invented a personal fantasy through textual pieces and performative utterances to create a space for himself: "Now the Kansai dialect's all I speak-at school, at home, even when I talk in my sleep. My dialect's near perfect, don't you think?" (p. 61) "As a kid, I was a huge Hanshin Tigers fan," Kitaru explained. "Went to their games whenever they played in Tokyo. But if I sat in the Hanshin bleachers wearing their jerseys and spoke with a Tokyo dialect, nobody wanted to have anything to do with me. Couldn't be part of the community, $y^{\prime}$ know? So I figured, I gotta learn the Kansai dialect, and I worked like a dog to do just that". Their conversation grows more surprising, and the narrator becomes more curious: "That was your motivation? I could hardly believe it" (p. 62).

Kitaru's obsession with the Kansai dialect and the narration of his experience is noteworthy. The sensitive narrator depicts Kitaru's distorted relationship with the mother dialect, which indicates the character's neurotic suffrage. Kansai is more of a regional dialect, including recognisable and exclusive vocabulary and pronunciation. The dialect spoken in Kobe is not the standard dialect commonly used in Tokyo. “When 
someone from Tokyo hears a Kansai accent, they associate a personality with the accent: warm, outgoing, and relaxed, also a little brash and outspoken, something that is so counter to ordinary Japanese custom as to be shocking" (Murakami, 2014, p. 64). What is more, the dialect has subcategories in itself. The standard Japanese language "has a distinctly reserved, assertive, gruff tone, something fitting for the business, governmental, and military center that Tokyo is" (p. 64). There is an underlying criticism against the identification of the accent with personality. That is such a cultural drawback in the eye of the writer that you can recognise the different accents and the regions of the people to grow prejudice against them. But Kitaru's story and language are neither of those. It just makes heard "emotional richness" (p. 75)

\section{Revisiting storyteller on the shore: Scheherazade}

Scheherazade constructs and saves her present through telling the stories of the past. It can be argued that Scheherazade, already having a powerful self, remakes/ recreates herself out of the act of storytelling and develops a new identity, which endows her narration with an actional function. The storyteller in Murakami's story, corresponding to the hypotextual precursor as mimicry in the eyes of Habara, the focalizer, reveals herself to have fictional "lives". The first life is a figurative (metaphorical) invention taking place in the fantasy world of the character; the second one is her episodic memory re-constructed and refreshed in mind; and lastly, she holds the role of a storyteller, "captivating" her addressee. She exerts her power not solely with her sensual seduction - but with her stories. The original Scheherazade attaches herself to the present by exploiting the invention; Murakami's Scheherazade attaches herself to the act of storytelling to re-animate the lived past. ${ }^{4}$

Table 2: Transformative Taxonomy of Scheherazade

\begin{tabular}{|l|l|l|}
\hline $\begin{array}{l}\text { Hypotext: One Thousand and One Night } \\
\text { Hypertext: Scheherazade }\end{array}$ & serious transformation & (=transposition) \\
\hline $\begin{array}{l}\text { Author } \\
\text { The implied author }\end{array}$ & playful imitation & (=pastiche) \\
\hline $\begin{array}{l}\text { Character: } \\
\text { The narrator's emphatic perspective: }\end{array}$ & serious transformation & (=transposition) \\
\hline $\begin{array}{l}\text { Character : } \\
\text { The Focaliser's empathic perspective: }\end{array}$ & serious transformation & (=transposition) \\
\hline
\end{tabular}

4 Murakami, exerts his wry humour and acute irony here in comparing the novelists and storytellers to lampreys. 
Metafictional consciousness of the character in "Scheherazade" explores the limits of oral and written limits of the act of storytelling and writing. Habara, the central character whose focalisation orients the story, is, figuratively put, shut in a shell. His residence becomes an unknown realm of fancy and fantasy, where Scheherazade's past experience transforms into exploration through storytelling. The isolated chamber opens up endless possibilities of connotations overwhelming the diachronic boundaries of history and attaching itself to a synchronic web of textual relationships - the naming of the act wrought by Habara, which signs his sensitivity to the realm of narration. Murakami presents the reader with a reversal of the storytelling medium even though he keeps the gender registers (female narrator and male narratee). The power relations between the actants and their psychological bonds, implications and motivations are changed and reversed. The former represents a Sultan retaining power and control over the narrator, who regains her control only through storytelling to extend her life span (Murakami, 2014, p. 116). That is an attempt to manage the future. The latter presents the reader with a shut-in, somewhat imprisoned man, having no control over the narrator neither in the story world nor in the fantasy world. This time, the narrator tries to control her past, trying to recover from past anguish and wounds. Thus, Murakami's Scheherazade'nurses' both Habara and herself.

The episodic memory of Habara is represented in the form of the very story (the text) in Scheherazade as the episodic memory of the first-person narrator is represented in the form of the very story (the text) in Yesterday. These texts keep their intertextual relationship with the external texts (Beatles' 'Yesterday' and One Thousand and One Nights), and the storytellers keep on a non-linear narrative interaction. Even though Kitaru does not care about his invention of a new song of'yesterday' or Habara has no idea whether Scheherazade's stories are her inventions or not, their performance as such help them to live on:"Reality and supposition, observation and pure fancy seemed jumbled together in her narratives" (Murakami, 2014, p. 115). Scheherazade's stories and storytelling is engaged with One Thousand and One Nights. The former has to do with survival through fantasy and invention; the latter has to do with therapy through factual past and invention. Hence, in both cases, the sexual relationship becomes an accompanying natural act of storytelling, and "the bed" turns into a figurative device. The bed is associated with sleep, dream, fancy, forgetting, restoring and therapy. The theme in the former is death; the theme of the latter is health/ life. That Habara does not know her name (he refers to her as Scheherazade) implies that she constructs a textual/discursive realm of existence. Her storytelling after they have sex brings about 
intimacy to their sterile affair. So-called Scheherazade regularly visits him only once a week, long enough for them to have time in bed, which brings a ritualistic aspect to Habara's very simple life. Scheherazade's nursing service and housework heal Habara while their bed ritual heals Scheherazade. Her libidinal energy is expressed and released in the form of sexual intercourse and the fictional invention of the stories. In terms of the motif of storytelling and multi-part story, it is akin to the One Thousand and One Nights' Scheherazade, but, as regards the past story of her teenage love, storytelling turned into a therapy session. Yet, Scheherazade ceases to tell a story abruptly, never achieving the ultimate cure. The intrusion of the temporal life outside interrupts her spatial engagement, and Habara has to wait for the next visit. Such a storytelling device also indicates an intertextual relationship with an overt reference to the previous text from the perspective of the narrator. This is a story within a story, not a metafictional gesture, yet indicates a self-conscious character regarding literary references.

The episodic memory represented by Scheherazade during the bed rituals retrospects a teenager's love story. She broke into the house of a classmate whom she never talked to at school and who never noticed her before. She recurrently visits (breaks into) the flat until the door's locks are changed. The boy's mother presumably apprehends the visits. Scheherazade said that she could not creep into the boy's privacy and enjoy obsessive clandestine stealing (Murakami, 2014, p. 128). Her storytelling shows that Scheherazade ostensibly loses her interest in the game, but she still tells about the boy. In fact, she mourns for the game hindered by the external force and her repressed fantasy. An attentive reader might realise that her story never ended, and its episodic memory is still alive.

The invisible distance between Habara and Scheherazade is noteworthy, although they share a palpable intimacy as well as stories. The metaphor of lamprey is an explicative figure at this point since Scheherazade figuratively steals lives to keep on her story world. Such critical distance between the layers of the texts results in Habara's eventual realisation, and it is Scheherazade's imagination that orients their "story" (p. 136). Scheherazade, making a reference to the precursor tale in which the authority is taken over by the female narrator within a domestic realm of fantasy, reproduces the previous case with the recurrent theme of imprisonment. Both the Sultan in the tale and Habara are confined to the chamber of the female narrator, textually, sexually and socially determined by the storyteller. Men occupy vital and particular roles in women's lives, but their roles are defined by the female storytellers. The end of the affair/storytelling, in the case of Scheherazade, is at the hands of the woman. Habara is not only sensible 
but also sensitive to the feelings of Scheherazade and likes to keep on attuning himself to her actions. His careful, kind and submissive responsiveness lets the female storyteller stay longer in bed and in his life. On the other hand, we can say that Habara fears that she can go invisible if he disturbs her with questions: As for Habara, the isolated substitute for the Sultan seems devoid of power: "What did bother him, though, was the thought of not being able to talk in bed with Scheherazade. Or, more precisely, missing the next installment of her story" (p. 118). The isolated man's fear to lose the woman's companionship reveals his need for spatial liberation through the stories as well as socialisation. He just leaves himself to her drives and desirous yet somewhat painful motives until the moment when they leave silently. Habara, the knowledgeable and sensitive character, readily conceives the case of Scheherazade, growing a considerable curiosity about her stories, an interest in her storytelling and her mimicry of the classical tales of Scheherazade in their privacy. The fact that Habara seems to know about the end of the story and his homodiegetic status as a character in that "tale" shows that Habara envisages for himself an 'extradiegetic position'keeping outside of the world of whom he calls the storyteller Scheherazade. At this point, Habara is confined to the stories of both the third-person narrator and Scheherazade, which marks an allegorical correspondence with his house arrest.

The past is under the shadow, and the future is unknown in Scheherezade. The characters are entrapped within an eternal present, in a negative sense, which does not bring relief. Stimulating mystery surrounds the entire story because we do not know anything about the characters, neither the caretaker woman nor the home-stick man. The explicit reference to One Thousand and One Nights holds 'explicative' and 'actional' functions at a time. Habara is alienated from different perspectives: To the story world of Scheherazade (the character), to the current external world (setting in the story), and to the woman whom he calls Scheherazade (the storyteller in Habara's fantasy world). The hypotex One Thousand and One Nights assigns him a new identity -that of a powerful Sultan having authority. This temporary sense of freedom liberates the character spatially (textually). Therefore, he seems to have delighted Scheherazade's stories and storytelling as much as having sex, probably more than it.

All the stories told by Scheherazade paved the way for the final tale, a sign of their relationship, which is a passionate exchange of emotions, relieving desire and releasing of libidinal energy. Habara's untold anxiety is apparent in: "what his time spent with women offered was the opportunity to be embraced by reality, on the one hand, while 
negating [reality] entirely on the other." Once edging such a refined assumption, he commences fantasising how it is to be a "lamprey", unseen in the weeds. At some point, Scheherazade tells the homebound character Habara about her "love story" (124). It was an awkward, somewhat obsessive and unusual story of intrusion into one's own life, having much to do with her mind inventions rather than spiritual love. This was likely to be due to her extreme shyness, and repressed feelings of desire manifested through the exchange of trivial objects (her stealing the boy's shirt and leaving behind her panties, an exchange of the personal belongings, in which the objects turn out to be signs and the relationship gains a semiologic relationship, which continues in her relationship with Habara, an ongoing process of signification, and a continuous exchange of emotions. They never exchange their names; that is, Scheherazade never calls Habara by his name, nor does she tells Habara her name.

The underpinnings of the story are not devoid of situational irony, and considering Japanese culture, the strong and storytelling female character, indicates a deconstructive desire to undermine the patterns of self-contained male characters and silent and passive female types. Scheherazade is clearly unconventional (undermining the stereotype of traditional "geisha" through storytelling). Scheherazade-the storyteller attains an 'author-ity' over Habara and experiences a spatial expansion through storytelling on different levels: from a wordless and reliant / parasite (metaphor of lamprey) nurse/servant to a talkative and independent actant (storyteller), an equivocal partner in bed (p. 115, p. 117) She deconstructs the conventional master/slave binary in a way that it reminds Habara of the Sultan and Scheherazade in One Thousand and One Nights. What is more, the story undermines the hierarchies through the act of sexuality and textuality, both revealing an active agency of Scheherazade. It is the woman who breaks into the houses (those of the classmate boy and Habara) and into lives and privacy. The metatextual implication is provided by the character (Habara) calling the storyteller woman Scheherazade, which hints at the possible fantasies and stories about the identities of these characters. The readers, who are puzzled by quite a few mysteries in the story, are invited to "write/tell" their alternative stories, signifying endless possibilities of hypertexts, a mimicry of the case of original Scheherazade, the hypotext. Beyond Habara's undisclosed microcosmic world, the possible worlds, which the implied reader would fantasise about, change the text into an incomplete "text" floating in the synchronous web of the texts. The open-endedness highlighted by the implied author, therefore, is so significant that it turns Murakami's story into a modern chapter in One Thousand and One Nights, with which the story gains further meanings. 
Princess Scheherazade's proclivity for telling stories after sex in One Thousand and One Nights is a significant repeated pattern in Murakami's story. The hypertextual allusion is indirect, and an authorial gesture manifested through Habara's perception. Habara tells us about how their involvement in the act of storytelling in the fashion of the classical tales: "Her voice, timing, pacing were all flawless. She captured her listener's attention, tantalised him, drove him to ponder and speculate" (p. 116, p. 118). Here, it is seen that both Scheherazade and Habara are concerned with storytelling and take it seriously. Habara's naming her "Scheherazade" (p. 114) is a sign of respect and awe as well as desire. A storytelling woman is capable of creating an episodic memory on the part of the man, who can be officially or unofficially a house-convict as a writer. Habara, as a participant-observer, gives some clue that he has a penchant (and skill) to tell the stories, which makes him a lamprey in Scheherazade's terms.

All in all, storytelling in Scheherazade turns out to be both declarative statements having a message to deliver and illocutionary act having a particular effect on the hearer (Habara). Storytelling in her stories appear to be both "saying" and "doing" at a time, as is the case with sexual intercourse, which is both a praxis (performance) and a means of semiotic expression: "She barely spoke during their lovemaking, either, performing each act as if completing an assignment" (Murakami, 2014, p. 117). Thus, storytelling and sex actualise their potential in the levels ranging from text to performance or from performance to text (p. 123). The text (story) and performance (storytelling) reveal the implied author's exerted and deeply wrought exploration of the human experience, if not a self-conscious playfulness.

\section{Conclusion}

As Habara's cryptic notes in his diary imply that stories are cryptic notes of the authors which need deciphering, Yesterday and Scheherazade, transforming the previous texts, provide new contexts for the story worlds and exemplify two cases of non-linearity in storytelling. What is more, for all their openness, these stories hardly direct the reader's response, denying the right ways and wrong ways of reading. Instead, they foreground the act of re-writing and storytelling in different ways. The texts are displaying the readers' interaction, who in these two specific cases appear to be the narrators. It seems that Murakami characteristically and deliberately chooses links to the other texts, violating the linear progression of the act of storytelling. The recurrent motifs of storytelling, memory and keeping a diary glimpse at the conviction that any story, with 
the help of deciphering the references, allusions, pastiches, makes a vivid and polyphonic pool of prospective stories. These hypertexts do not contain 'a satirical content' and carefully avoid the vulgarity of caricature; instead, they represent textual and performative responses to the hypotexts. That indicates Murakami's attempt to change the potential meanings of the previous stories. Hence, ongoing mutual dialogue is presumed between the hypertexts and hypotexts. Murakami uses hypertextual elements as a narrative strategy and frequently represents storyteller characters whose embedded stories have a critical -and core- role in the frame narrative.

Secondly, Murakami's fictional narratives Yesterday and Scheherazade explore the actional function in two hypertextual narratives and represent the storytellers in search of narrative and performative relief in a far-fetched world of everyday life. These stories explore whether storytelling can transform everyday experience into something special or episodic memory worth telling (Murakami, 2010, October). It is seen that both storytellers achieved telling their stories filled with episodic memories. The moon scene in Yesterday and episodic experience in the final scene of Scheherazade are indicators of such release. Kitaru, as an inventor of his song, and Scheherazade, as an unreliable storyteller, represent their phantasm in their verbal performances.

Thirdly, the characters tell stories in order to cling to life, but in each attempt, they just hold on to their imaginary fantasies. In Yesterday, the narrator seeks restoration and relief in telling the story of an ordinary man, and in Scheherazade, the storyteller tries to make her daily experiences special. They both reproduce them in the mediation of art and take shelter in the hypertexts they produce. Scheherezade's metaphor of "lamprey" perhaps hints at the collected details from others' lives and using them in her stories. These somewhat obsessive, reserved and isolated characters escape from the annoying and anxious world through the fulfilment of actional function. It is observed that libidinal energy is discharged by written and oral storytelling.

In a nutshell, these stories produce hypertexts on different levels and, in Eco's terms, present the reader with elusive 'open works' from the perspective of modern critical theory. The "intentions implicitly manifested" by the author (Eco, 1979, p. x) are sophisticated by the intentions of the storytellers, who are frequently seen undermining the authority of the implied author. Moreover, we remember White's argument that "narrative becomes a problem only when we wish to give to real events the form of story" (Waugh, 267). Murakami's storytellers, then, reverse the direction, giving their 
inventions the form of reality. The gaps are, therefore, mostly due to these characters and their mysterious li(v)es opening up to new fictional, textual and'actional' possibilities. These stories are hypertexts having a relationship with previous texts and narrative performances indicating actional function. Always offering new possibilities of reading and interpretation, these stories provide their storytellers with remarkable healing power.

Peer-review: Externally peer-reviewed.

Conflict of Interest: The author has no conflict of interest to declare.

Grant Support: The author declared that this study has received no financial support.

Hakem Değerlendirmesi: Dış bağımsız.

Çıkar Çatışması: Yazar çıkar çatışması bildirmemiştir.

Finansal Destek: Yazar bu çalışma için finansal destek almadığını beyan etmiştir.

\section{References}

Allen, G. (2000). Intertextuality. London: Routledge.

Aronson, L., Tenenbaum, S. \& Roures, J. (Producers) \& Allen, W. (Director). (2011). Midnight in Paris. United States: Versatil Cinema.

Chambers, R. (1984). Story and situation: narrative seduction and the power of fiction. Minneapolis: Manchester University Press.

Coleredge, S. T. (1982 [1878) The rime of the ancient mariner. New York: Dover Publishing.

Eco, U. (1989). The open work. Trans. A. Cancogni. Cambridge: Harvard University Press.

Genette, G. (1982) Narrative discourse: an essay in method. Trans. Jane E. Lewin. Ithaca: Cornell University Press.

Genette, G. (1992 [1979]) The Architext. Trans. Jane E. Lewin. Ithaca: Cornell University Press.

Genette, G. (1997 [1982]) Palympsests, narrative in the second degree. Trans. C. Newman \& C. Doubinsky. Lincoln: University of Nebraska Press.

Irwin, R. (2004). The Arabian Nights: A companion. London: Tauris Park Paperbacks.

Joyce, J. (2016 [1922]). Ulysses. London: Penguin.

Jullien, D. (2019). Bridge Essay: Orientalia. A Companion to World Literature. Ed. K. Seigneurie. John Wiley \& Sons Ltd.

Kristeva, J. (1989). Black sun: depression and melancholia. New York: Columbia University Press.

Mathers, E.P., Ed. (2004 [1964]). The book of the thousand nights and one night (vol. 1), London: Routledge.

Strecher, M.C. \& Thomas, P.L. Eds. (2016) Haruki Murakami. Critical literacy teaching series: challenging authors and genres. Rotterdam. Sense Publishers. 
McCartney, P. \& Lennon, J. (1965). Yesterday [Lyrics]. On the album Help!. Retrieved from https://genius.com/ The-beatles-yesterday-lyrics

Mukherjee, S. \& Swamy, S.K. (2019). Redefining Masculinity in Haruki in Murakami's Men Without Women. Shanlax International Journal of English, vol. 8, no. 1, pp. 67-70.

Murakami, H. (2010) "Reality A and reality B. New York Times." Global Agenda 29 Oct. 2010.

Murakami, H. (2017 [2014]) Men without women. Trans. Philip Gabriel. New York: Vintage.

Murakami, H. (2000). Norwegian wood. Trans. Jay Rubin. New York: Vintage Vintage.

Murakami, H. (2005). Kafka on the Shore. Trans. Philip Gabriel. New York: Vintage.

Poole, S. (2011). "1Q84 by Haruki Murakami - Review." Guardian 18 Oct. 2011.

Rimmon-Kenan, S. (2002 [1983]) Narrative fiction: contemporary poetics. London: Routledge.

Strecher, M. (2002). Dances with sheep: The quest for identity in the fiction of Murakami Haruki.

Michigan, MI: University of Michigan.

Yeung, H. (2014). More than the Sum of its Parts': Popular Music, Gender, and Myth in Haruki Murakami's Fiction. Transnational Literature, Vol. 7 no. 1, November Issue.

Yeung, V. (2016): Stories Within Stories: A Study of Narrative Embedding in Haruki Murakami's 1Q84, Critique: Studies in Contemporary Fiction.

Waugh, P. (1994). Metafiction: The theory and practice of self-conscious fiction. London: Methuen. 
